\title{
DINAMIKA TEATER TRADISIONAL MENDU DI KALBAR (1712 - 2014)
}

THE DYNAMICS OF MENDU TRADITIONAL THEATRE IN WEST KALIMANTAN (17D-2014)

\author{
Dewi Juliastuty \\ Balai Bahasa Provinsi Kalimantan Barat \\ Jln. Ahmad Yani Pontianak, 78121 \\ e-mail: djuliastuty@yahoo.co.id
}

Naskah Diterima:2 Januari $2014 \quad$ Naskah Direvisi:10 Februari $2014 \quad$ Naskah Disetujui:18 Februari 2014

\begin{abstract}
Abstrak
Mendu adalah teater tradisional di Kalimantan Barat. Mendu berasal dari Kabupaten Pontianak, terpusat di Dusun Malakian Desa Sengkubang Kecamatan Mempawah Hilir. Masa jaya teater mendu pada tahun 1876-1942. Tahun 1980 mendu bangkit kemudian menjadi primadona dan berkembang pesat di Provinsi Kalimantan Barat selama tahun 1980-an. Perlahan mendu meredup dan akhirnya mati suri. Masalah dalam kajian ini adalah bagaimana dinamika mendu di Kalbar. Tujuannya adalah mendeskripsikan dinamika mendu di Kalimantan Barat. Teknik pengumpulan data adalah wawancara dan studi dokumentasi. Metode yang digunakan adalah kualitatif dan didukung oleh pendekatan sosiologi sastra serta menggunakan teori sosiologi teater. Kajian ini merupakan kajian awal sehingga berpeluang dilakukan kajian lanjutan. Simpulan penelitian ini adalah mendu Kalimantan Barat merupakan penggabungan antara wayang Cina dengan syair Melayu. Keberadaan mendu di Kalbar mengalami pasang surut. Semakin derasnya arus globalisasi membuat mendu semakin tersisih pada zaman modern. Jika hal ini dibiarkan, maka kesenian mendu bukan hanya mati suri bahkan punah. Oleh karena itu, diperlukan dukungan dan tindakan nyata pemerintah dan masyarakat untuk menghidupkan kembali dan melestarikan mendu.
\end{abstract}

Kata kunci: mendu, teater tradisional.

\section{Abstract}

Mendu is a traditional theatre in West Kalimantan. Mendu Theatre is from Pontianak, in Malakian Sengkubang village, Mempawah Hilir sub district. The Golden era of Mendu theatre was around 1876-1942. In 1980, Mendu Theatre raised and became the greatest and drew up in the province of West Kalimantan. As time as goes by, the theatre was abandoned. The question of the research is about the dynamics of Mendu Theatre in West Kalimantan. The purpose of the research is to describe of mendu theatre cycle in West Kalimantan. The techniques of collecting the data are in depth interview and documentation studies. The method is qualitative method, and also uses the theory of literature and theatre sociology. This research is only the beginning and it will continue. The summary of this research mendu theatre in west Kalimantan was the collaboration of Chinese puppet with Malay's verse. Globalization impact is one of the biggest factors that affecting mendu theatre's. If this problem still appeared, then the result is mendu theatre will vanish. Government alongside the society should take an action in conserving the Mendu Theatre.

Keywords: mendu, traditional theatre. 


\section{A. PENDAHULUAN}

Teater mendu merupakan warisan budaya Indonesia yang kian terlupakan dan tersisihkan oleh pengaruh westernisasi dan lajunya arus globalisasi. Kehidupan teater mendu di Provinsi Kalimantan Barat mengalami pasang surut. Masa kejayaan teater mendu pada tahun 1876-1942. Berakhirnya masa kejayaan teater mendu karena Jepang melarang bangsa Indonesia untuk berserikat dan berkumpul. Orang yang melanggar aturan ini ditangkap dan mendapatkan siksaan yang keji dari Jepang. Hal tersebut menyebabkan teater mendu tidak pernah lagi dipentaskan karena orang-orang takut mereka akan dicurigai pihak Jepang kemudian ditangkap dan disiksa secara keji.

Ternyata, setelah Indonesia merdeka selama puluhan tahun pun teater mendu tidak pernah dipentaskan bahkan nama mendu tidak pernah lagi terdengar. Teater mendu menjadi sesuatu yang asing karena masyarakat tidak mengetahui mengenai teater mendu yang dulu sangat digemari dan berjaya sebelum masa penjajahan Jepang terhadap Indonesia. Sedikit orang yang mengetahui mendu dan mereka umumnya adalah generasi tua.

Kondisi mati suri teater mendu mendorong pemerintah untuk menggali, menghidupkan, dan mengembangkan teater mendu dengan cara melakukan diskusi dan sarasehan dengan masyarakat dan para seniman pada tahun 1978 dan 1979. Aksi ini berlanjut dengan aksi para seniman teater mementaskan mendu pada tahun 1980 yang menjadi awal kebangkitan mendu. Selanjutnya teater mendu mendapat sambutan baik dari masyarakat, bahkan menjadi primadona dan menyebar luas dan pesat disertai munculnya berbagai sanggar mendu di penjuru Provinsi Kalimantan Barat. Selama tahun 1980-an teater mendu sangat populer dan menjadi primadona.

Perlahan sejak tahun 1990-an popularitas teater mendu meredup tidak lagi menjadi primadona di masyarakat. Hingga kini, pertunjukan mendu sulit ditemui. Satu di antara alasan penyebab mendu jarang dipentaskan karena hampir tidak ada penerusnya—orang yang mau menjadi pemain teater mendu. Nama mendu pun terasa begitu asing bagi masyarakat. Kini, jarang ada orang yang mengenal tentang teater mendu. Kehidupan manusia era modern memberikan banyak pilihan hiburan bagi masyarakat. Teater mendu bukanlah satu-satunya pilihan untuk dijadikan hiburan masyarakat. Derasnya arus globalisasi berdampak pada makin tersisih teater mendu dari kemajuan zaman dan masyarakat. Berbagai upaya yang dilakukan pemerintah dan masyarakat tidak mampu mencegah atau setidaknya memperlambat kepunahan teater mendu.

Hal ini sungguh miris karena teater mendu bukan sekadar pertunjukan teater rakyat yang mampu menghibur masyarakat pada masa kejayaannya. Namun, teater mendu merupakan seni pertunjukan yang menjadi media penyimpan adat dan pengetahuan budaya lisan masyarakat khususnya Melayu Kalimantan Barat melalui perpaduan musik, tari, lagu, syair, dialog, pencak silat, dan banyolan/humor yang membuat suasana jadi akrab antara pemain dan penonton karena komunikatifnya dialog-dialog spontan yang kadang-kadang melibatkan penonton. Teater mendu juga menjadi media pendidikan dalam masyarakat terutama kepada generasi muda dengan menyampaikan nilai-nilai luhur kehidupan manusia karena setiap pementasannya selalu berakhir dengan kemenangan kebaikan terhadap kejahatan merupakan pakem dalam teater mendu. Oleh karena itu, kondisi teater mendu menuju kepada kepunahan tidak boleh dibiarkan terjadi begitu saja. Hal ini juga telah menjadi keprihatinan Odhy's pada beberapa tahun yang silam. Buat mengetahui wajah sendiri kita mesti mengetuk pintu rumah tetangga dan meminjam cermin mereka. Lantaran cermin yang ada dalam rumah sudah sangat buram karena tak pernah disentuh. Maka saya pun lantas berpikir, andai laju gerak si bule tak kita dahului (atau 
minimal diimbangi), bukan mustahil bilamana ingin menonton mendu atau membaca sastra kesultanan Kalbar, kelak kita harus melacaknya di luar negeri (Odhy's, 2003:61).

Berdasarkan uraian di atas, masalah penelitian ini adalah bagaimana dinamika teater mendu di Kalimantan Barat (17122014). Oleh karena itu, tujuan penelitian ini adalah mendeskripsikan dinamika teater mendu di Kalimantan Barat (1712-2014). Dalam penelitian ini digunakan pendekatan sosiologi sastra sehingga penelitian difokuskan pada fungsi teater mendu bagi masyarakat serta pandangan masyarakat terhadap teater mendu. Pandangan masyarakat pada teater mendu mempengaruhi tujuan keberadaan teater mendu. Hal ini yang mendorong masyarakat untuk memelihara dan melakukan pementasan teater mendu atau sebaliknya. Perubahan pandangan masyarakat terhadap teater mendu mempengaruhi kondisi teater mendu.

\section{B. METODE PENELITIAN}

Teknik pengumpulan data dilakukan dengan cara wawancara dan studi dokumentasi. Wawancara dilakukan oleh peneliti baik secara langsung maupun tidak langsung dengan cara tanya jawab untuk mendapatkan data penelitian. Selain itu, pengumpulan data melalui studi dokumentasi dilakukan peneliti dengan membaca berbagai teks mengenai mendu. Metode yang digunakan dalam penelitian ini adalah metode kualitatif dan menggunakan pendekatan sosiologi sastra.

\section{HASIL DAN BAHASAN}

\section{Asal-usul dan Awal Kehidupan Teater Mendu}

Terdapat berbagai versi mengenai asal-usul Kesenian mendu Kalimantan Barat. Versi pertama menyatakan bahwa mendu bermula dan dikembangkan pada tahun 1712, versi kedua adalah pada tahun 1871, dan versi ketiga adalah pada tahun 1876.

Peneliti menemukan versi pertama terdapat dalam buku yang berjudul
Ungkapan Beberapa Bentuk Kesenian (Teater, Wayang, dan Tari) bahwa dalam sebuah buku tua bertuliskan huruf Arab Melayu-yang disimpan oleh Pak Mukminin Noerman (dedengkot mendu tua) di Desa Malakian, Semudun Kabupaten Pontianak dijelaskan bahwa kesenian mendu bermula dikembangkan pada 1712. Ide itu datang dari seorang penembahan di Kerajaan Mempawah ketika itu. Untuk kepentingan ini, konon menurut sejarahnya lahirlah suatu mufakat atas ajakan penembahan tadi dengan beberapa orang kawan sepergaulannya untuk mengembangkan mendu. Sejak itulah mereka mulai aktif mementaskan kesenian mendu yang sangat pesat perkembangannya di Desa Semudun, tepatnya di Kampung Malakian. Dalam waktu yang relatif singkat mendu sudah dikenal oleh masyarakat lingkungannya serta amat disenangi.

Mendu ini pun makin berkembang luas di beberapa desa di Kabupaten Pontianak, seperti Desa Mengkacak, Sungai Kunyit, Sengkubang, dan beberapa desa lainnya. Cerita dari mulut, akan asyiknya nonton mendu ini terdengar juga ke telinga Raja Mempawah ketika itu, sehingga raja berkenan untuk menyaksikannya di alun-alun Istana Mempawah. Sejak itulah kesenian mendu diresmikan oleh sang raja sebagai kesenian rakyat di Kabupaten Pontianak-menurut sejarahnya pada tahun 1776 (Achmad et. al (ed.), Tanpa Tahun terbit:80_81).

Peneliti menemukan dua buah referensi yang mengacu pada versi kedua. Referensi pertama, yaitu sebagian besar dari teater tradisional rumpun Melayu adalah bersumber dari cerita rakyat atau hikayat. Demikian halnya teater rakyat mendu mulai populer di Kepulauan Riau dan Kalimantan Barat pada sekitar tahun 1871 Masehi adalah cerita rakyat yang menceritakan Hikayat Dewa Menduputra Semadun, yaitu dewa dari kayangan (Soren, 2003:90).

Referensi kedua, yaitu alkisah menurut sejarahnya bahwa tiga orang putra 
Mempawah dari Kampung Malekian Desa Semudun. Ketiga orang pemuda tersebut adalah Ahmad Antu, Ahmad, dan Kapot yang pulang merantau dari negeri Brunai (sekarang dikenal dengan nama Brunei Darussalam) dengan jalan darat melalui Sambas.

Sekitar tahun 1871, di tempat asalnya itu mereka mengabdikan diri guna memajukan masyarakat di lingkungannya. Masing-masing mengabdi dengan keahliannya atau keterampilan yang mereka kuasai.

Ahmad Antu mengajar pencak silat. Ahmad memberantas buta huruf, mengajarkan tulis baca dan Kapot mengajar mengaji.

Pada waktu luang setelah mereka selesai mengabdi seperti yang telah dipaparkan di atas, mereka bersama muridmuridnya sering berlatih kesenian (diilhami sebuah kesenian yang pernah mereka saksikan di Brunei). Sampailah pada suatu ketika mereka akan naik pentas menampilkan kesenian itu, tetapi mereka bingung akan diberi nama apa kepada kesenian yang akan mereka pentaskan nanti. Kebetulan cerita yang pertama kali mereka pakai untuk latihan dan akan dipentaskan itu berjudul Dewa Mendu. Oleh karena itu, mereka sepakat memberi nama kesenian itu dengan nama Kesenian Mendu (Ramli, 2000:1-2).

Versi ketiga, yaitu ...konon menurut kisahnya kira-kira pada tahun 1871 tersebutlah tiga orang putra dari Kota Mempawah ini yang pada saat itu masih merupakan sebuah kerajaan, pergi merantau ke Kalimantan Utara yaitu menuju ke Kerajaan Brunei karena antara raja di Brunei ada hubugan keluarga dengan raja dari Mempawah. Ketiga putera Mempawah yang pergi merantau itu adalah masing-masing bernama Amat Antu, Achmad, dan Kapot.

Lima tahu lamanya mereka merantau dan bermukim di Brunei dan akhirnya mereka pun rindu kepada kampung halamannya. Pepatah juga mengatakan hujan emas di negeri orang, tetapi masih lebih baik hujan batu di negeri sendiri dan di mana pun kita pergi, maka sirih akan tetap pulang kepada ganggangnya dan pinang pulang ke tampuknya. Demikian pulalah ketiga putra Mempawah tadi, walaupun sudah lima tahun merantau mengadu nasib dan peruntungan serta menuntut ilmu, rupanya tergerak di hati mereka untuk pulang ke Mempawah. Banyak berjalan, maka banyak yang mereka lihat dan kaya pula pengalaman mereka sehingga mereka dapat membuat perbandingan dan tidak seperti katak di bawah tempurung yang merasa paling agung di dunianya itu. Ketiga putra Mempawah tadi tertarik pada sebuah kesenian di Brunei dan dapat mempelajari kesenian tersebut. Besar kemungkinan mereka mempelajarinya hanya sebagai pengisi waktu luang untuk menghilangkan rasa rindu kampung halaman, sambil menyelam minum air, sekali merengkuh dayung dua tiga pulau terlampaui. Kesenian yang mereka pelajari itu sekarang disebut mendu.

Alkisah mereka pun pulang menuju tempat asalnya yaitu Mempawah melalui Sambas. Terbersit di hati mereka untuk menetap beberapa waktu di Kerajaan Sambas sambil mencoba mengembangkan kesenian yang didapat selama di peratauan. Namun, mereka belum berhasil karena belum dapat diterima masyarakat setempat yang masih kuat tradisinya dan kondisinya masih belum memungkinkan.

Mereka kemudian melanjutkan perjalannya kembali ke Mempawah. Mereka bertiga mengabdikan diri memajukan masyarakat lingkungannya dengan masing-masing bertugas dengan keahlian dan keterampilan yang didapatnya di perantauan. Amat Antu bertugas mengajar silat, Achmad memberantas buta huruf dengan mengajarkan menulis dan membaca, dan Kapot bertugas mengajar mengaji. Pada waktu luang setelah selesai mereka bertugas seperti di atas, mereka terkenang kembali kesenian Mendu yang sudah didapatnya dan mencoba 
mengajarkannya kepada anak-anak asuh mereka.

Rupanya kesenian mendu cukup menarik perhatian para murid mereka sehingga berhasrat untuk ikut bermain dalam lakon Mendu. Demikianlah selanjutnya kesenian ini hidup subur di kalangan masyarakat setempat dan akhirnya terdengar oleh pihak Kerajaan Mempawah dan raja pun sangat tertarik dan menyukai kesenian tersebut. Pada hari besar, Mendu selalu diminta oleh pihak kerajaan mementaskan mendu untuk menghibur rakyat. Begitu pula pada malam hari setelah panen dan pada waktu mereka tidak dalam kesibukan sebagai pelipur lara mereka melakukan pementasanpementasan di masyarakat. Dengan demikian jadilah kesenian mendu ini milik rakyat (Bidang Kesenian Kantor Wilayah Prov. Kalbar Depdikbud Proyek Pengembangan Kesenian Kalbar, 19831984:8-9).

Berdasarkan paparan di atas, maka pada versi ketiga diketahui bahwa tiga orang putra Mempawah, yaitu Amat Antu, Achmad, dan Kapot merantau ke Brunei pada tahun 1871. Lima tahun kemudian, yaitu tahun 1876 mereka kembali pulang ke kampung halamannya dan mengajarkan teater mendu juga kepada murid-muridnya. Oleh karena itu, dapat disimpulkan bahwa teater mendu pertama kali masuk di provinsi Kalimantan Barat pada tahun 1876.

Bahan sastra lisan dapat dibedakan menjadi tiga bagian, yakni:

a. bahan yang bercorak cerita: (a) ceritacerita biasa (tales), (b) mitos (myths), (c) legenda (legends), (d) epik (epics), (e) cerita tutur (ballads), (f) memori (memorates),

b. bahan yang bercorak bukan cerita: (a) ungkapan (folk speech), (b) nyanyian (songs), (c) peribahasa (proverbs), (d) teka-teki (riddles), (e) puisi lisan (rhymes), (f) nyanyian sedih pemakaman (dirge), (g) undangundang atau peraturan adat (law), c. bahan yang bercorak tingkah laku (drama): (a) drama panggung dan (b) drama arena (Hutomo dalam Endraswara, 2013:151-152).

Bentuk teater yang dinamakan Mendu ini dikenal di tiga wilayah yaitu, di Malaysia, Riau, dan Kalimantan Barat. Mendu Riau dikatakan mendapat pengaruh dari Bangsawan, sedangkan Mendu Malaysia adalah sinonim dari wayang Parsi dan ada sebelum Bangsawan. Tampak bahwa dalam bidang teater tradisi terdapat masalah peristilahan yang serupa dengan apa yang terdapat pada seni tontonan, atau tari khususnya, pada wilayah Jawa-Bali, berbagai istilah bisa mewakili bentuk-bentuk yang sama atau mirip, dan sebaliknya satu istilah bisa digunakan untuk berbagai bentuk. Dalam hal teater ini sebab perbedaan dan persamaan itu kadang-kadang jelas: bentuk-bentuk teater diberi nama menurut nama peran atau juga nama cerita yang dibawakannya, misalnya Mendu dari Dewa Mendu, dermuluk dan badamuluk dari Abdul Muluk. Cerita-cerita yang sama itu dimainkan di berbagai daerah oleh bentukbentuk teater tradisi yang tidak sama. Dengan demikian, bentuk penyajian Mendu di Malaysia pada akhir abad yang lalu mungkin cukup banyak berbedanya dengan Mendu Riau yang berbeda juga dengan Mendu Kalimantan Barat. Demikian pula Mamanda Kalimantan Selatan beda dengan Mamanda Kalimantan Timur. Dalam hal ini perlu dicatat bahwa seni yang dinamakan Mendu tidak hanya memainkan cerita Dewa Mendu (Sedyawati, 1981:45-46).

Ditilik dari bentuknya mendu dapat digolongkan ke dalam teater rakyat atau teater tradisional. Kehidupan seni teater di Indonesia dapat dibagi menjadi dua golongan walaupun secara lahiriah dan tegas sukar untuk dibedakan karena keduanya hidup berdampingan dan saling mengisi serta saling mempengaruhi. Namun, perbedaan yang satu dengan yang lainnya dikarenakan oleh perbedaan sumber, wawasan, cita rasa pendukungnya 
dan teknik pengolahannya. Kedua golongan tersebut adalah:

\section{a. Teater Tradisional}

Teater tradisional juga disebut teater daerah yang beraneka ragam coraknya di Indonesia yang disebabkan pula negara Indonesia terdiri dari aneka ragam suku bangsa yang mengakibatkan pula beraneka ragam corak kebudayaannya. Akan tetapi, keanekaragaman corak ini yang menggambarkan spesifik kedaerahannya sendiri, mempunyai ciri-ciri umum atau utama bahwa semua dilakukan secara improvisatoris, dilakukan secara spontan, menggunakan bahasa daerah masingmasing, semua cara penyajiannya di samping gerak dan dialog, juga dilakukan sambil menyanyi, menari, dan selalu diwarnai dengan lelucon, banyolan atau dagelan.

Yang tergolong dalam kelompok teater tradisional ini adalah:

\section{1) Teater Rakyat}

Teater rakyat sifatnya sederhana, spontan, dan menyatu dengan kehidupan rakyat. Contohnya sebagai berikut:

- Mendu di Kalimantan Barat,

- Makyong di Riau,

- Mamanda di Kalimantan Selatan,

- Ketoprak di Jawa Tengah,

- Dermuluk di Sumatera Selatan,

- Ludruk di Jawa Timur dan lain-lain.

2) Teater Klasik

Sifat teater klasik adalah teater yang sudah mapan, kebanyakan lahir di pusatpusat kerajaan (keraton) dan sudah mempunyai hasil puncak. Contohnya wayang kulit, wayang orang, wayang golek, dan wayang gong.

3) Teater Transisi

Teater transisi sebenarnya bersumber dari teater tradisional, tetapi gaya penyuguhannya sudah dipengaruhi teater barat. Teater jenis ini seperti zaman Teater Bangsawan dan lebih populer dengan nama Sandiwara. Contohnya Sandiwara Srimulat (Surabaya), Sandiwara Sunda (Jawa Barat), dan Sandiwara Bangsawan (Sumatera Selatan dan Utara).

\section{b. Teater Modern}

Bentuk teater ini didasarkan pada lakon tertulis hasil karya sastra, diikat oleh hukum dramaturgi. Susunan pengolah banyak didasarkan pada teknik teater barat. Lakon-lakon yang dipentaskan selalu karya-karya pengarang sastra yang selalu menciptakan lakon-lakon baru. Diutamakan adalah ceritanya sendiri, bukan jalan cerita, mengutamakan konflik dan masalah, mengutamakan problematik lengkap dengan perwatakan tokohtokohnya (Bidang Kesenian Kantor Wilayah Prov. Kalbar Depdikbud Proyek Pengembangan Kesenian Kalbar, 19831984: 11-13).

Mendu Kalimantan Barat merupakan penggabungan antara wayang Cina dengan syair Melayu. Pengaruh wayang Cina nampak pada perwatakan (cara main/pembawaan) tokoh jin yang seperti wayang Cina di dalam pertunjukan mendu. Kostum yang digunakan tokoh jin tidak mendapat pengaruh dari wayang Cina. Kostum tokoh jin adalah celana, kaus kaki, wig (rambut palsu) yang terbuat dari tali rapiah. ${ }^{1}$

Selain itu, teater adalah ekspresi dunia di sekitar kita. Teater jelas sastra pertunjukan. Tidak akan memperoleh kejelasan makna, apabila sosiologis teater hanya mengamati teks. Lewat teater, orang dapat memainkan kisah apa saja. Dunia teater pada masa lalu senantiasa jaya, karena memang telah memiliki andil dan mengubah kehidupan. Kelompok teater laskar, gandrik, sega gurih adalah teater tradisional. Teater dapat berkembang karena ada medianya. Banyak arena teater yang secara sosial menggambarkan dunia sosial (Endraswara, 2011:210).

Selanjutnya, teater itu produk akumulasi masyarakat. Berbagai kejadian sosial selalu diangkat dalam teater. Itulah eksistensi sosial dalam teater. Sebaliknya, teater juga berada dalam lintasan sosial.

\footnotetext{
${ }^{1}$ Komunikasi pribadi pada 26 Februari 2013 dengan Ilham Setiawan, S. Sn.--pelaku seni di Kalbar.
} 
Jika lintasan sosial ini mendukung teater, maka akan ada perkembangan yang signifikan (Endraswara, 2011:223).

Pertunjukan teater siap mulai setelah seluruh perangkat siap. Masyarakat sebagai penonton harus berada di tengahtengah teater. Teater berada di tengah masyarakat dan masyarakat juga hadir di jagad teater. Itulah hubungan timbal balik antara teater sebagai karya seni dan sastra sosial. Teater itu menjadi saksi imajinasi masyarakat(Duvignaud dalam Endraswara, 2011:223).

Materi mendu merupakan bentuk seni pertunjukan rakyat. Berdasarkan pengamatan terhadap mendu, baik strukturnya, ciri-ciri dan cara pementasannya, mendu dapat digolongkan dalam kelompok seni pertunjukan rakyat (teater rakyat).

1) Pementasan didahului oleh bunyi tetabuhan (musik), gong, bedug, gendang dan diiringi bunyi biola.

2) Diikuti oleh tampilnya tokoh-tokoh pendukung yang sambil menari dan menyanyi, sebagai salam perkenalan kepada penonton.

3) Dilakukan secara improvisasi (spontan).

4) Materi pokok cerita yang diambil dari babad, hikayat, seribu satu malam, epos, atau cerita lama dan kadang kala dicampur juga dengan kehidupan masyarakat setempat.

5) Musik, tari, dan lawakan merupakan bagian integral dari pertunjukan.

6) Dialog dilakukan dalam bahasa daerah.

7) Tidak ada naskah lengkap, kecuali alur cerita yang dikisahkan oleh mahnijar (sutradara) secara lisan kepada para pelaku (ketika latihan).

8) Pementasan dilakukan di atas panggung dengan dekorasi yang sangat sederhana, yaitu lukisan di atas kain atau triplek (menggambarkan hutan, istana, dan sebagainya).

9) Antara pemain dan penonton terpisah oleh panggung.
10) Penggantian babak ditandai dengan tertutupnya layar, bunyi tetabuhan yang disesuaikan dengan kondisi tempat pementasan.

11) Pakaian disesuaikan dengan materi yang dibawakan.

12) Jumlah pemain disesuaikan dengan materi cerita.

13) Simpulan pada setiap cerita yang dipentaskan senantiasa harus menggambarkan kebenaran diletakan di atas segala kebatilan.

14) Pertunjukan ditutup dengan nyanyi sebagai tanda perpisahan dan mohon maaf kepada penonton apabila terdapat kesalahan-kesalahan (Achmad et. al (Ed),Tanpa Tahun Terbit:84-85).

Fungsi kesenian mendu dalam masyarakat adalah sebagai:

\section{a. Media Hiburan}

Mendu merupakan teater rakyat yang lahir di tengah masyarakat untuk menghibur masyarakat. Mendu menjadi media hiburan karena ditonton oleh masyarakat secara gratis. Para penonton dibuat larut dan dibawa sejenak pada dunia yang lain sehingga terlupakanlah sejenak segala macam permasalahan dan keruwetan hidup mereka. Mereka menikmati pertunjukan yang ditampilkan oleh para pelakon dan para pemusik. Keterpaduan musik, tari, lagu, dialog, dan banyolan/humor yang membuat suasana menjadi asyik. Tingkah laku dan banyolan pemain dengan berbagai perangainya membuat suasana menjadi tambah hidup dan semarak sehingga pertunjukan tersebut menjadi semakin menarik.

\section{b. Media Ungkap Rasa Estetis.}

Teater mendu menjadi media ungkap rasa estetis para seniman dan penikmat seni teater rakyat ini. Keterampilan serta kepekaan para seniman terhadap nilai-nilai estetis tersalurkan melalui teater mendu yang mereka tampilkan. Keterampilan dan kepekaan mereka terhadap nilai-nilai estetis yang 
terkandung dalam mendu akan semakin terasah dengan semakin seringnya para seniman berlatih dan tampil menghibur masyarakat. Selain itu, rasa estetis para penikmat seni pertunjukan mendu dapat disalurkan dengan mereka menyaksikan pertunjukan mendu. Teater mendu menjadi media ungkap rasa estetis para penikmatnya. Kegemaran bahkan kecintaan mereka terhadap mendu juga akan meningkatkan apresiasi mereka terhadap seni.

\section{c. Media Pendidikan.}

Meskipun ditemukan di semua budaya, dari segi tertentu narasi lebih berfungsi luas dalam budaya lisan primer ketimbang dalam budaya lain. Pertama, dalam budaya lisan, pengetahuan tidak dapat dikelola dalam kategori-kategori yang kurang lebih bersifat abstrak dan ilmiah. Budaya lisan tidak dapat menghasilkan kategori-kategori seperti itu, jadi digunakanlah cerita-cerita mengenai tindakan manusia untuk menyimpan, menata, dan mengomunikasikan sebagian besar hal yang mereka ketahui. Sebagian besar kalau bukan semua budaya lisan menghasilkan narasi atau rangkaian narasi dalam jumlah yang cukup banyak, seperti kisah-kisah perang Troya di kalangan masyarakat Yunani kuno, cerita-cerita coyote, sejenis anjing hutan, di kalangan berbagai penduduk Amerika Asli, ceritacerita Anansi (laba-laba) di Belize dan budaya-budaya Karibia lain yang memiliki warisan budaya Afrika, kisah-kisah Suniata dari Mali lama, kisah-kisah Mwindo di kalangan masyarakat Nyanga, dan seterusnya. Karena ukuran dan kerumitan adegan serta tindakannya, narasi semacam ini kerap kali merupakan gudang penyimpanan terluas bagi adat dan pengetahuan suatu budaya lisan. Kedua, narasi sangat penting dalam budaya lisan primer karena bisa mengikat sejumlah besar adat dan pengetahuan dalam bentuk yang relatif panjang, besar, serta cukup tahan lama-yang dalam budaya lisan berarti bentuk-bentuk yang akan diulang (Havelock dalam Ong, 2013:211-212).

Berkaitan dengan pendapat di atas, maka pertunjukan mendu digunakan untuk mengisahkan mengenai tindakan manusia untuk menyimpan, menata, dan mengomunikasikan sebagian besar hal yang mereka ketahui, yaitu berupa kebaikan dan kebenaran selalu menang melawan kejahatan dan keburukan. Oleh karena itu, mendu menjadi media pendidikan karena dalam setiap pertunjukannya/cerita selalu berakhir dengan kemenangan kebaikan terhadap kejahatan. Kebaikan selalu mengalahkan kejahatan. Hal tersebut menjadi pakem dalam

Pertunjukan mendu mengandung pesan-pesan yang penting dan hendak disampaikan kepada masyarakat. Mendu merupakan peninggalan lelukur yang bernilai budaya dan diwariskan dari satu generasi ke generasi berikutnya. Oleh karena itu, pertunjukan mendu mengandung nilai budaya yang dapat digunakan sebagai media pendidikan. Nilai budaya tersebut merupakan pesan-pesan sebagai sumber pengetahuan dan pendidikan yang hendak disampaikan kepada generasi selanjutnya yang mengandung nilai-nilai luhur dan kebajikan yang seharusnya diteladani dan diaplikasikan oleh generasi mudagenerasi penerus.

Teater mendu juga dapat menjadi gudang penyimpanan terluas bagi adat dan pengetahuan suatu budaya lisan karena ukuran dan kerumitan adegan serta tindakannya. Hal ini tampak di dalam pertunjukan mendu dengan adanya perpaduan musik, tari, lagu, syair, dialog, pencak silat, dan banyolan/humor yang membuat suasana jadi akrab antara pemain dan penonton karena komunikatifnya dialog-dialog spontan yang kadang-kadang melibatkan antara pemain di panggung dengan penonton di sekitar panggung atau pentas. Suasana menjadi bertambah hidup dan asyik oleh tingkah laku banyolan pemain dengan berbagai perangainya. 
Figur jin yang ganas dan buas, raksasa, serta perkelahian yang menggunakan pencak silat tergambar pada alur cerita biasanya membuat tontonan menjadi semakin menarik. Mendu sebagai sebagai media hiburan sekaligus menjadi media penyimpan adat serta pengetahuan budaya masyarakat Kalimantan Barat.

Selain itu, narasi sangat penting dalam budaya lisan primer. Oleh karena itu, pertunjukan mendu mengikat sejumlah besar adat dan pengetahuan yang memberikan tuntunan dan menata kehidupan manusia dalam bentuk pertunjukan yang relatif panjang, besar, serta cukup tahan lama-dalam budaya lisan berarti bentuk-bentuk yang akan diulang.

d. Media Penyampai Pesan, misalnya Pesan Pembangunan.

Pertunjukan mendu sebagai media hiburan juga dapat berfungsi sebagai media penyampai pesan pembangunan. Pada tahun 1980-an pertunjukan mendu sebagai hiburan yang ditonton masyarakat diselipkan pesan-pesan-visi dan misi pembangunan, program $\mathrm{KB}$, bahkan pada waktu pemilu dapat memberikan andil yang banyak sebagai media penerangan, pendidikan, dan penyampaian misi pembangunan.

Selain itu, membicarakan teater mendu sebagai pertunjukan sastra lisan yang lahir dan hidup di masyarakat tidak dapat dipisahkan dengan masyarakatnya. Pertunjukan sastra lisan mempunyai fungsi sosial bagi masyarakatnya, seperti mengaktifkan fungsi fatik bahasa, mengaktifkan komunikasi antaranggota masyarakatnya, membagi berita sosial, serta mensosialisasikan nilai sosial kepada anak-anak (Amir, 2013:9).

Berkaitan dengan pendapat di atas, maka mendu juga memiliki fungsi sosial bagi masyarakatnya, yaitu mengaktifkan fungsi fatik bahasa, mengaktifkan komunikasi antaranggota masyarakatnya, membagi berita sosial, serta mensosialisasikan nilai sosial kepada anak- anak. Mendu berfungsi mengaktifkan fungsi fatik bahasa karena bahasa yang digunakan dalam pertunjukan mendu bukanlah bahasa asing dan tidak dikenal oleh masyrakatnya. Namun, menggunakan bahasa yang dikenal oleh masyarakatnya, yaitu bahasa yang dimiliki dan digunakan oleh masyarakat tersebut (bahasa Melayu) sehingga masyarakat merasa terikat dengan teater mendu karena teater mendu merupakan bagian dari masyarakat. Oleh karena itu, anggota masyarakat sebagai bagian dari masyarakat akan merasa terikat dengat masyarakatnya termasuk mendu .

Pertunjukan mendu mengaktifkan komunikasi antarwarga masyarakatnya ketika mendu dipentaskan. Pertunjukan mendu menjadi kesempatan warga masyarakat untuk bertemu dan berkomunikasi dengan warga lainnya atau orang-orang yang jarang ditemui, bahkan hampir tidak pernah bertegur sapa karena kesibukan masing-masing.

Pertunjukan mendu membuka peluang kepada warga masyarakat yang menonton mendu secara beramai-ramai untuk berkomunikasi dengan sesama warga, meskipun tanpa pertunjukan mendu pun komuniksasi antarwarga bisa terjadi. Namun, komunikasi antarwarga masyarakat yang terjalin ketika menonton pertunjukan mendu dilakukan dalam suasana yang santai dan menyenangkan sehingga meleburlah batas-batas pemisah-yang selama ini menjadi dinding pemisah pergaulan antarwarga dan memungkinkan antarwarga masyarakat menjadi lebih akrab serta lebih mengenal satu dengan yang lainnya. Hal ini bisa mempererat hubungan dan kepedulian antarwarga masyarakat. Oleh karena itu, antarwarga masyarakat akan cenderung menghindari permusuhan, saling menjaga, dan tolong-menolong sehingga terciptalah kehidupan bermasyarakat aman, damai, dan harmonis.

Selain itu, terjadi dialog langsung antara pemain mendu dengan penonton. Pemain mendu mengajak penonton untuk terlibat dialog secara spontan dalam 
pertunjukan mendu. Hal tersebut menimbulkan suasana akrab antara pemain dan penonton.

Fungsi sosial pertunjukan mendu membagi berita sosial maksudnya adalah pertunjukan mendu dapat dijadikan sebagai media penyampai cerita atau peristiwa yang sedang hangat terjadi di masyarakat. Selain itu, pertunjukan juga dapat dijadikan sebagai media penyampai pesan pembangunan.

Fungsi sosial yang terakhir, yaitu pertunjukan mendu mensosialisasikan nilai sosial kepada anak-anak. Pertunjukan mendu tidak sekadar untuk menghibur, tetapi menjadi media pendidikan kepada anak-anak. Mereka merupakan generasi muda yang akan meneruskan pembangunan bangsa, maka diharapkan anak-anak ini memiliki jiwa dan budi pekerti yang luhur karena masa depan bangsa dan negara ini kelak akan bergantung kepada mereka. Oleh karena itu, setelah menyaksikan pertunjukan mendu mereka diharapkan mengetahui nilai-nilai luhur, menjunjung tinggi, dan mengaplikasikannya dalam kehidupan nyata sehari-hari. Pada akhirnya anak-anak menjelma menjadi manusia Indonesia yang memiliki jiwa dan budi pekerti yang luhur.

\section{Masa Kejayaan Teater Mendu (1876- 1942)}

Sejak tahun 1876 tercatat masa jaya kesenian mendu hingga tahun 1943 (masa penjajahan Jepang). Pada waktu itu selain berkembang di Kabupaten Pontianak, yaitu Mempawah, Mendu juga berkembang di Ngabang, Sambas, Sungai Raya, Sungai Duri, Singkawang, dan Sekura. Di Kabupaten Sanggau antara lain di Tayan dan Balai Karangan. Di Kabupaten Ketapang antara lain di Sungai Awan Kiri, Suka Baru, Sukadana, Simpang Hilir (Achmad et. al (Ed),Tanpa Tahun Terbit:81). Selain itu, tahun 80-an juga menjadi masa kebangkitan sekaligus masa keemasan seni Mendu setelah mati suri dalam kurun waktu yang lama. Sekitar tahun 1942 — masa pendudukan Jepang, ketakutan masyarakat kepada orang-orang Jepang menyebabkan mereka tidak berani mengadakan berbagai kegiatan termasuk pertunjukan mendu. Sejak saat itulah mendu tidak pernah dipentaskan lagi kemudian mati suri dalam kurun waktu yang lama (Soren, 2003:93).

Faktor-faktor pendorong masa kejayaan teater mendu di Kalimantan Barat adalah sebagai berikut:

a. Teater mendu mendapat sambutan yang baik dari masyarakat pada masanya sehingga menyebar ke berbagai kabupaten di Provinsi Kalimantan Barat.

b. Teater mendu diayomi oleh Panembahan Kerajaan Mempawah.

c. Panembahan menyenangi teater mendu sehingga ia menjadi pengayom dan sponsor teater mendu. Panembahan Mempawah menjadikan teater mendu sebagai hiburan gratis bagi rakyatnya.

d. Jenis hiburan yang ada sangat terbatas pada masa jayanya teater mendu.

e. Kehidupan masyarakat yang sederhana dan tradisional menyebabkan sangat terbatasnya jenis hiburan sehingga teater mendu berkembang pesat dan menjadi media hiburan yang sangat digemari masyarakat.

f. Banyolan segar dan khas teater mendu sangat digemari masyarakat.

\section{Masa Kemunduran Teater Mendu (1942- Awal $\mathbf{1 9 8 0}$ dan 1990-an- Masa Kini)}

Teater mendu mengalami kemunduran bahkan mati suri pada masa penjajahan Jepang-1942 hingga awal tahun 1980-an. Kesenian ini kembali hidup pada tahun 80-an dan perlahan meredup pada tahun 90 -an hingga akhirnya mati suri pada masa kini.

Faktor-faktor penyebab masa kemunduran teater mendu di Provinsi Kalimantan Barat adalah sebagai berikut:

a. Penjajahan Jepang di Indonesia.

Pada masa penjajahan Jepang, semua organisasi kebangsaan yang telah berdiri sejak zaman Hindia Belanda dibubarkan. Hal ini sesuai dengan 
Undang-undang Bala Tentara Jepang Nomor 2 Tanggal 8 Maret 1942 yang berisi melarang bangsa Indonesia berserikat dan berkumpul. Segenap pelanggaran terhadap undang-udang ini akan ditindak oleh dinas polisi rahasia Jepang, yaitu Kempetai dengan siksaan yang sangat kejam. ${ }^{2}$ Oleh karena itu, sejak berlakunya UU tersebut, maka teater mendu pun tidak pernah dipentaskan karena masyarakat takut ditangkap dan disiksa oleh Kempetai. Oleh karena itu, teater mendu mengalami mati suri bahkan hingga Negara Kesatuan Indonesia merdeka pun kondisi ini masih terus berlanjut.

Sataruddin Ramli menuturkan ${ }^{3}$ bahwa dahulu jangankan menyaksikan pertunjukan mendu, bahkan orang-orang belum pernah mendengar nama mendu. Malah nama mendu terasa asing di teliga. Dahulu mendu mengalami mati suri pada masa penjajahan Jepang dan berlanjut setelah perang dunia II. Dari tahun 1944 s.d. 1979.

b. Pembangunan lebih difokuskan pada pembangunan sektor fisik.

Kearifan lokal adalah pengetahuan asli (indigineous knowledge) atau kecerdasan lokal (local genius) suatu masyarakat yang berasal dari nilai luhur tradisi budaya yang mengatur tatanan kehidupan masyarakat dalam rangka mencapai kemajuan komunitas baik dalam penciptaan kedamaian maupun peningkatan kesejahteraan masyarakat. Kearifan lokal itu mungkin berupa pengetahuan lokal, keterampilan lokal, kecerdasan lokal, sumber daya lokal, proses sosial lokal, norma etika lokal, dan adat istiadat lokal.

\footnotetext{
2 Perpustakaan Cyber, "Dampak /Pendudukan Militer Jepang di Indonesia di Dalam Bidang Politik" diakses dari http://perpustakaan cyber.blogsport.com, tanggal 12 Maret 2014, pukul 22.00 WIB.

${ }^{3}$ Wawancara pada 2008 dengan Sataruddin Ramli-pakar Mendu Kalbar.
}

Dalam kenyataan sekarang, implementasi kearifan lokal itu semakin menurun sehingga sulit ditemukan manusia, pemimpin, dan pengambil keputusan yang bijaksana dalam melaksanakan tugasnya dalam suatu komunitas. Bahkan, pemimpin dan pengambil keputusan sama sekali tidak mengetahui manfaat kearifan lokal dalam pembangunan. Kenyataan ketidaknyambungan (missmatch) dalam berbagai program pembangunan yang terjadi di Indonesia dianggap karena kearifan lokal tidak sejalan atau tidak diperhitungkan dalam pembangunan. Program pembangunan yang dirancang selama ini tidak menjawab masalah-masalah yang dirasakan masyarakat secara langsung. Oleh karenanya, kajian, revitalisasi, dan implementasi kearifan lokal sangat perlu dilakukan agar terbentuk mamusia yang bijaksana dan pemimpin yang benar-benar menjawab kebutuhan rakyat.

Kekurangpahaman mengenai pentingnya nilai budaya merupakan faktor utama kenapa kearifan lokalnya tidak mendapat perhatian dalam pembangunan. Masih ada orang yang menganggap bahwa tradisi budaya tidak relevan dengan kehidupan modern sekarang ini, padahal negara atau bangsa yang berhasil membangun kesejahteraan rakyatnya adalah bangsa yang membangun berbasis budayanya. Sekarang ini, Cina dan Jepang masing-masing negara pertama dan ketiga tersejahtera (terkaya) peringkat dunia dan kedua negara ini membangun dengan berbasis pada budaya rakyatnya. Sering sekali pembangunan bangsa kita dikaitkan dengan pencarian "untung" (profit). Bukan pencarian "manfaat" (benefit), padahal meskipun segala-galanya memerlukan uang, tidaklah uang segala-galanya. Kebudayaan dan kearifan lokalnya memang tidak langsung memberikan untung secara ekonomis, tetapi secara perlahan-lahan kearifan lokal sebagai warisan masa lalu itu akan memberikan manfaat untuk peningkatan kesejahteraan dan pembentukan kedamaian rakyat 
melalui karakter yang kuat generasi mudanya (Sibarani, 2013:20-21).

c. Westernisasi dan derasnya arus globalisasi.

Kendala lain adalah munculnya pendapat/anggapan generasi muda bahwa seni pertunjukan mendu ketinggalan zaman bahkan kuno sehingga sangat sulit melakukan regenerasi seni pertunjukan mendu. Di samping itu, para seniman mendu umumnya sudah lanjut usia dan banyak yang sudah meninggal dunia. Para pemain juga sibuk bekerja yang umumnya berprofesi sebagai petani dan nelayan sehingga tidak punya kesempatan untuk menampilkan mendu (Selamat, 2007:8).

Selain itu, peneliti temukan pada tahun 2008 bahkan pada beberapa minggu yang lalu (Februari 2014). Ternyata, hanya sedikit orang yang mengetahui tentang mendu, bahkan mereka tidak pernah mendengar mengenai sesuatu yang bernama mendu. Mereka yang tidak tahu mengenai mendu malah balik bertanya kepada peneliti mengenai mendu.

d. Tidak ada yang menjadi pengayom teater mendu dan sponsor tetap teater mendu.

Perhatian pemerintah yang kurang dan tidak ada regenerasi mengakibatkan kondisi kesenian mendu sekarang ini mengalami mati suri. Maksud istilah mati suri adalah sanggar-sanggar mendu masih ada dan tidak dibubarkan. Namun, sanggar-sanggar tersebut tidak pernah lagi melakukan aktivitas latihan dan tampil di muka umum. ${ }^{4}$

Abdul Hamid Satoh mengungkapkan berbagai kendala yang dihadapi para seniman mendu sehingga mereka hampir tidak lagi menampilkan seni pertunjukan ini $^{5}$, yaitu pertama adalah

\footnotetext{
${ }^{4}$ Wawancara pada 26 Februari 2013 dengan Ilham Setiawan, S. Sn.-pelaku seni di Kalbar.

${ }^{5}$ Wawancara pada 2008 dengan Abdul Hamid Satoh—seniman Mendu Kalbar sekaligus ketua Sanggar Mendu Bestari.
}

pakaian yang mereka gunakan dalam pertunjukan adalah pakaian sewaan dan alat tetabuhan/bunyi-bunyian sudah rusak. Namun, mereka tidak memiliki dana untuk menyewa pakaian dan memperbaiki alat musik yang rusak atau membeli yang baru apabila ingin menampilkan pertunjukan mendu, karena penonton menikmati penampilan mendu secara gratis dan para seniman mendu memainkan pertunjukan ini tanpa bayaran. Padahal zaman sekarang sulit mendapatkan sponsor berbeda seperti zaman dahulu. Pendapat senada lainnya bahwa dengan artis yang cukup banyak termasuk para penabuh musik dan para teknisi ditambah lagi dengan segala perlengkapan pentas dan konsumsi pasti memerlukan biaya yang besar. Padahal pertunjukan bersifat hiburan untuk masyarakat di tempat terbuka dan umumnya tidak dipungut biaya. Oleh karena itu, mulai dari sutradara sampai pemain, pakaian, dan makanan disediakan dan diatur oleh mereka semua secara gotong royong dengan niat untuk menghibur penduduk/masyarakat miskin di kampungnya. Kalau kebetulan ada panitia perayaan atau mendu ditampilkan pada acara perkawinan, tentu biaya dipikul oleh pihak yang punya hajat. Namun, itu hanya untuk keperluan pementasan, sedangkan pemain termasuk sutradara tidak perlu disediakan honornya. Mereka sudah merasa bangga kalau pertunjukan berjalan lancar dan penonton pulang dengan rasa puas. Kadangkala ada pula sponsor yang bersedia membiaya pementasan mendu ini. Segala sesuatunya dilakukan dengan keikhlasannya. Akan tetapi, zaman sekarang sponsor sulit dicari karena orang lebih memilih memanggil musik dangdut atau mengadakan pertunjukan layar tancap saja pada acara perkawinan sehingga Mendu Melayu terpinggirkan. Apalagi minat orang muda untuk menjadi sutradara, artis, dan tenaga teknis juga sulit ditemui (Selamat, 2007:8). 
4. Masa Kebangkitan Kembali Teater Mendu (Awal 1980-1980-an dan Masa Kini)

Kebangkitan kembali teater mendu yang mati suri selama puluhan tahun diawali pada awal tahun 1980. Sekitar satu dekade, yaitu tahun 1980-an mendu kembali mencapai masa kepopulerannya. Namun, pada tahun 1990-an popularitas teater mendu meredup dan akhirnya mati suri hingga sekarang.

Faktor-faktor pendorong masa kebangkitan kembali teater mendu pada tahun 1980-an adalah sebagai berikut:

a. Peran aktif pemerintah melakukan diskusi dan sarasehan untuk menggali dan menghidupkan kembali kesenian mendu.

Tanggal 5 November 1978 dilakukan diskusi dan sarasehan yang diikuti oleh Kepala Sub Dit Seni Teater, Film, dan Sastra Direktorat Pembinaan Kesenian Jakarta beserta staf dan Kepala Bidang Kesenian Kantor Wilayah Departemen Pendidikan Kebudayaan Kalbar beserta staf dibantu para petugas kebudayaan di Kabupaten Pontianak serta tokoh-tokoh tua kesenian mendu dengan tujuan sebagai upaya menggali dan menghidupkan kembali kesenian mendu tersebut.

Tanggal 11 s.d. 14 November 1979 dilakukan sarasehan dan studi terhadap kesenian ini dan kali ini juga diikuti oleh beberapa tokoh muda dari kelompok teater modern baik yang ada di Kotamadya Pontianak maupun yang ada di Kabupaten Pontianak. Para seniman teater muda ini pun bertekad untuk memelihara seni tradisional daerahnya, khususnya mendu dan berusaha mengembangkannya.

\section{b. Para seniman teater menggali dan mementaskan teater mendu.}

Para seniman teater yang tergabung dalam Sanggar Teater Gelanggang Seni Budaya Pontianak yang dipimpin Sataruddin Ramli sejak 1980 mulai menggali dan mementaskan mendu di Kotamadya Pontianak. Untuk menarik perhatian para pemuda-pemuda agar mencintai seni tradisi ini dilakukan garapan-garapan yang disesuaikan dengan masa kini, tetapi dengan tidak menghilangkan ciri-ciri khas atau kerakyatannya terutama dalam hal busananya. Kelompok mereka cukup berhasil sehingga pada waktu pemilu dapat memberikan andil yang banyak sebagai media penerangan, pendidikan, dan penyampaian misi pembangunan. Bahkan, Maret 1980 menjadi awal mendu mulai berkembang mereka berhasil menggalakkan dan memperkenalkannya ke luar Kalbar melalui festival, pekan dan duta seni, serta media (Bidang Kesenian Kantor Wilayah Prov. Kalbar Depdikbud Proyek Pengembangan Kesenian Kalbar, 1983-1984: 10-11).

c. Para seniman teater muda bertekad untuk memelihara seni tradisional daerahnya, khususnya mendu dan berusaha mengembangkannya sehingga mucul banyak sanggar mendu di Provinsi Kalimantan Barat.

Selain itu, kembali, mulai dari Kotamadya Pontianak, Kabupaten Pontianak, Kabupaten Sambas, Ketapang, Sanggau sampai di Kabupaten Kapuas Hulu. Tercatat adanya delapan belas buah grup mendu di daerah Kalbar (Achmad et. al (ed), Tanpa Tahun Terbit:82—83).

d. Berbagai upaya dilakukan untuk penyebarluasan mendu supaya dikenal dan diterima masyarakat.

Pada bulan Maret 1980 kesenian mendu mulai populer kembali karena sering dipentaskan di Pontianak, beberapa kabupaten di Kalbar, sering diutus mengikuti festival oleh Kanwil Depdikbud Kalbar, Kanwil Deppen Kalbar ke tingkat nasional, TIM, TMII, Bandung, Semarang, Yogyakarta, Nganjuk, dan Banjarmasin. Pemda Kalbar selama beberapa tahun berturut-turut sudah mengangkat mendu ini dilayar TVRI melalui acara Budaya Nusantara dengan durasi 60 Menit (tahun 1980, 1982, 1983, dan 1984) yang menampilkan cerita yang 
berjudul Menghadang Maut di Simpang Tiga, Ilham Maulana Permata Dewi, Panglima Upari, dan Cembul Hikmat (Ramli, 2000:2).

Berbagai upaya yang dilakukan pemerintah untuk menghidupkan kembali teater mendu sebagai berikut:

Mendu pernah tampil di Taman Budaya Yogyakarta pada tahun 2005. Selain itu teater Mendu Kalbar yang diwakili Sanggar Tabir Budaya dari Sungai Kunyit dipilih masuk sepuluh besar terbaik sebagai peserta di Festival Pertunjukan Rakyat (FPR) Tingkat Nasional tahun 2011 yang diadakan oleh Kementerian Komunikasi dan Informasi RI. ${ }^{6}$ Festival tersebut diadakan di Solo pada tanggal 20 s.d. 24 Mei 2011. Ternyata, seni pertunjukan Mendu Kalbar menjadi pemenang dalam kategori pemenang hiburan. $^{7}$

Beberapa bulan yang lalu tepatnya tanggal 6 Desember 2013 MABM melaksanakan "Pementasan Seni Cemerlang-Melayu Gemilang" yang menampilkan pertunjukan mendu. Chairil dalam Asmirizani (2013) memaparkan bahwa MABM mendapat kepercayaan untuk menyelenggarakan fasilitasi rumah budaya dari Kementerian Pendidikan dan Kebudayaan. Dalam rangka fasilitasi tersebut MABM mengadakan berbagai kegiatan untuk menanamkan nilai dan mengembangkan budaya Melayu. Puncak kegiatan kegiatan berlangsung pada tanggal 6 Desember 2013 dengan melaksanakan Pementasan Seni Cemerlang-Melayu Gemilang. Acara tersebut menampilkan mendu dan tarian Melayu.

Ternyata, pertunjukan mendu yang diadakan MABM mendapat sambutan

\footnotetext{
${ }^{6}$ Dewi Juliastuty. "Gaung Mendu Masih Terdengar" dalam Borneo Tribun, 15 Mei 2011, hlm, 2.

${ }^{7}$ Kontributor Dishubprov, "Jawa Tengah Juara Pertama Festival Media Pertunjukan Rakyat Tingkat Nasional Tahun 2011" diakses dari http://www.jatengprov.go.id, tanggal 10 Maret 2013, pukul 9.30 WIB.
}

positif dari penonton yang jumlahnya ribuan orang. Mereka merasa terhibur dan senang dengan pertunjukan mendu meskipun pada awalnya mereka sama sekali tidak tahu mengenai mendu, bahkan ada yang datang ke acara tersebut karena penasaran mengenai mendu.

Kegiatan diadakan oleh MABM pertunjukan mendu yang 6 Desember 2013 "Pementasan Seni Cemerlang-Melayu Gemilang" yang menampilkan pertunjukan mendu adalah kegiatan yang positif dan bermanfaat bagi pelestarian seni pertunjukan mendu yang menuju kepunahan mengingat masyarakat sudah mulai melupakan mendu sehingga pertunjukan mendu menyusut.

\section{PENUTUP}

Pemerintah dan masyarakat telah melakukan berbagai upaya untuk menghidupkan kembali dan melestarikan teater mendu. Namun, hasil yang diharapkan belum tercapai. Berkaitan kesulitan upaya regenerasi seni pertunjukan mendu, menurut Ilham Setiawan $^{8}$ bahwa sulit melakukan regenerasi kesenian ini kepada kaum muda. Pelestarian kesenian ini adalah tugas kita bersama, yaitu pemerintah, pekerja seni, dan masyarakat. Oleh karena itu, hendaknya anak-anak seharusnya telah dikenalkan dengan kesenian ini sejak mereka berusia dini. Tantangan dalam upaya menggaet generasi muda supaya tertarik pada kesenian ini adalah "Bagaimana seniman mengemas (pakem) seni pertunjukkan mendu sehingga kesenian menjadi menarik tanpa menghilangkan pakemnya-identitas mendu.

Para penutur dan komunitas tradisi lisan semakin berkurang. Hal ini akibat proses pewarisan secara alamiah tidak berjalan sesuai dengan yang diharapkan, sementara perubahan kebudayaan berjalan

\footnotetext{
${ }^{8}$ Wawancara pada 26 Februari 2013dengan Ilham Setiawan-pelaku seni di Kalbar.
} 
dengan cepat. Dihadapkan pada kenyataan ini, satu-satunya yang penting dalam upaya menjaga tradisi lisan sebagai sumber ilmu pengetahuan pada masa sekarang dan akan datang adalah perubahan dalam sistem pewarisannya. Di sinilah peran penting perguruan tinggi dalam menyikapi dan menyiapkan program konkret dalam mengubah media pewarisan tradisi lisan tanpa meninggalkan hakikat tradisi itu sendiri yang tidak dapat dipisahkan dari komunitasnya (Pudentia, 2009:1).

Berdasarkan pembahasan di atas, maka diperlukan langkah-langkah sebagai berikut:

1. Sikap konsisten dari pemerintah, masyarakat, dan para seniman dalam upaya pengenalan seni pertunjukan mendu secara luas dan sering di masyarakat dengan seringnya mengadakan pementasan mendu. Bahkan, anak-anak seharusnya telah dikenalkan dengan kesenian ini sejak mereka berusia dini.

2. Diperlukan peran aktif dan konsisten dari pemerintah pusat dan daerah untuk melestarikan teater mendu, yaitu dengan cara:

a. mata pelajaran mulok khusus mengenai teater mendu untuk pelajar di Provinsi Kalimantan Barat,

b. Perguruan tinggi harus dapat mengembangkan referensi yang bersumber dari tradisi lisan. Tidak hanya berpusat pada literatur yang memuliakan kajian ilmu pengetahuan dalam bentuk baku yang tertulis. Oleh karena itu, perguruan tinggi mampu menyiapkan program konkret dalam mengubah media pewarisan tradisi lisan tanpa meninggalkan hakikat tradisi itu sendiri yang tidak dapat dipisahkan dari komunitasnya.

c. Pemerintah mempunyai program sering mengadakan lomba khusus pertunjukan mendu dari tingkat provinsi hingga di tingkat antarkampung.

d. Pemerintah sering mengadakan penataran kepada kalangan seniman, pelajar, mahasiswa, dan pemerhati seni mengenai seni pertunjukan Mendu.

3. Pemerintah berperan aktif dan konsisten menghimpun sanggarsanggar Mendu yang tidak aktif tapi masih ada anggotanya. Mengayomi mereka dengan tujuan menghidupkan kembali kesenian ini. Pemerintah juga memberikan bantuan kepada sanggarsanggar yang masih mengadakan kegiatan agar semakin maju. Kedua jenis sanggar ini menjadi sanggar binaan pemerintah. Langkah awal tapi dilakukan rutin adalah sering mengadakan pementasan mendu yang tidak bersifat kompetisi pada sanggarsanggar tersebut untuk membangkitkan gairah seniman mendu. Selanjtnya, sering diadakan lomba teater mendu supaya mereka semakin bersemangat.

4. Perlu adanya penelitian khusus dan mendalam mengenai teater mendu Kalimantan Barat karena kesenian ini sudah di ambang kepunahan. Hasil penelitian diharapkan menjadi dokumentasi teater mendu di Kalimantan Barat serta mengetahui identitas sesungguhnya dan hakikat teater mendu yang tidak dapat dipisahkan dari masyarakatnya sehingga kesenian ini dapat ditetapkan pemerintah menjadi Warisan Budaya Nasional bahkan diakui negara lain.

\section{DAFTAR SUMBER}

\section{Buku}

Achmad, A. Kasim et al. (ed). Tanpa Tahun Terbit.

Ungkapan Beberapa Bentuk Kesenian (Teater, Wayang, dan Tari). Jakarta: Direktorat Kesenian Proyek Pengembangan Kesenian Jakarta Departemen Pendidikan dan Kebudayaan. 
Achmad, A.Kasim. 2006. Mengenal Teater Tradisional di Indonesia. Jakarta: Dewan Kesenian Jakarta.

Amir, Adriyetti. 2013. Sastra Lisan Indonesia.Yogyakarta: Andi.

Bidang Kesenian Kantor Wilayah Prov. Kalbar Depdikbud Proyek Pengembangan Kesenian Kalbar. 1983-1984. Mendu Teater Rakyat Daerah Kalimantan Barat. Pontianak: Tidak Diterbitkan.

Dewi Juliastuty. "Gaung Mendu Masih Terdengar" Borneo Tribun, 15 Mei 2011.

Endraswara, Suwardi. 2011.

Metodologi Penelitian Sosiologi Sastra. Yogyakarta: Caps. 2013. Metodologi Penelitian Sastra (Epistemologi, Model, Teori, dan Aplikasi). Yogyakarta: Media Pressindo.

Kamaruddin, A. 1983-1984.

Mendu Teater Rakyat Daerah Kalbar. Pontianak: Bidang Kesenian Kantor Wilayah Prov. Kalbar Depdikbud Proyek Pengembangan Kesenian Kalbar.

Odhy's. 2003.

Nasib Mendu dan Sejumlah Renungan Sufistik Anak Melayu. Pontianak: Mulyatama.

Ong, Walter J. 2013.

Kelisanan dan Keaksaraan. Diterjemahkan oleh Rika Iffati. Yogyakarta: Gading.

Pudensia, MPSS. 2009.

"Tradisi Lisan sebagai Sumber Ilmu Pengetahuan". Menteng Wadas: Naskah yang tidak diterbitkan.

Ramli, Sataruddin. 2000.

Mempersembahkan Kesenian Mendu (Teater Tradisional Tanggal 3, 4, 5
November 2000): Brosur. Pontianak: Dewan Kesenian Kalimantan Barat.

Sibarani, Robert. 2013.

Folklor Sebagai Media dan Sumber Pendidikan: Sebuah Ancangan Kurikulum dalam Pembentukan Karakter Siswa Berbasis Nilai Budaya Batak Toba. Dalam Suwardi Endraswara (Ed). Folklor Nusantara (Hakikat, Bentuk, dan Fungsi): 21. Yogyakarta: Ombak.

Selamat. 2007.

Serial "Di Sela-Sela Rumput yang Hijau Antara Mendu, Budaya Melayu yang Tercecer, dengan Ketoprak Japon yang Terlupakan, dan Kedua Kutub Itu Bertemu di Garis Khatulistiwa". Naskah belum diterbitkan.

Sedyawati, Edi. 1981.

Pertumbuhan Seni Pertunjukan. Jakarta: Sinar Harapan.

Soren, Ellyas Suryani Bin. 2003. Legenda dan Cerita Rakyat Mempawah. Mempawah: Yayasan Insan Cipta Mempawah.

\section{Internet}

Asmirizani, "Chairil Berharap Apresiasi Terhadap Budaya Melayu Meningkat" diakses dari http://mabm online.org, tanggal 12 Februari 2014, pukul 10.54 WIB.

Kontributor Dishubprov, "Jawa Tengah Juara Pertama Festival Media Pertunjukan Rakyat Tingkat Nasional Tahun 2011" diakses dari http://www.jatengprov. go.id, tanggal 10 Maret 2013, pukul $9.30 \mathrm{WIB}$.

Perpustakaan Cyber, "Dampak /Pendudukan Militer Jepang di Indonesia di Dalam Bidang Politik" diakses dari http://perpustakaancyber.blogsport.com, tanggal 12 Maret 2014, pukul 22.00 WIB. 